\title{
昼光照明のエントロピー・エクセルギー解析 \\ A NUMERICAL ANALYSIS OF ARCHITECTURAL DAYLIGHTING IN TERMS OF ENTROPY AND EXERGY
}

\author{
浅田秀男*, 宿谷昌則** \\ Hideo ASADA and Masanori SHUKUYA
}

\begin{abstract}
This paper describes a method to calculate the entropy and exergy associated with architectural daylighting. The purpose for using these concepts is to show explicitly the irreversible energy conversion process of solar radiation incident upon glazing during the course of daylighting, and to provide a global understanding of how a daylighting system works. This method has been tested for a room having a single window with single clear or reflective glazing, each under a clear and an overcast sky. The result indicates that the exergy contained in solar radiation admitted by any daylighting system is first consumed by illuminating the requisite room surfaces while the entropy produced is given off as waste. So-called energy-efficient daylighting systems therefore selectively admit solar exergy to meet the illumination requirements.
\end{abstract}

keywords : daylighting, exergy, consumption, entropy, disposal

昼光照明、エクセルギー、消費、エントロピー、廃棄

\section{1. 研究目的}

太陽エネルギーは、一般にどのような方法で利用して も環境污染を引き起こすことはないとされている。この ようなことから、建策環境設借の分野においても様々な 太陽エネルギー利用技術の研究・開発が行われている。 それらの多くは太陽エネルギーの積極的利用による化石 エネルギー消費の代替を目標としている。しかし、これ らの研究・開発は「エネルギー消費」、「エネルギー利 用」の意味がいまひとつ不明瞭なままで行われている。 何故なら「エネルギーが消費される」と言うときの「エ ネルギー」は使えば减るエネルギーを指しているけれど も、エネルギー保存則によれば「エネルギー」は形を変 えるだけで、その量は常に一定なはずだからである。

減らない「エネルギー」が「消費される」と表現され ていることが、「エネルギーが消費される」ことの意味 を不明瞭に、また太陽エネルギー利用の意味をも不明瞭 にしていると考える。このような不明暸さは、エネル ギーの流れをエネルギー保存則に基づく観点からしか見 ていないために生じると考えられる。㷫学にはエネル ギー保存則のみならず、エントロピー増大則という重要 な法則がある。エネルギー保存則に加え、エントロピー
增大則をも考慮した観点からエネルギーの流れを見るこ とにより、「エネルギーが消費される」、「エネルギー を利用する」と一般に言われていることがより総合的に 理解できると考える。

以上のことから筆者らは建築環境論に関わる諸理論に エントロピー増大則を考慮すべきであると考える。具体 的には、建築環境システムのあらゆる活動の源となるも のの「資源性」おょび「消費」を明確に表わすのにエク セルギーを用い、消費の結果生みだされる廃熱・廃物の 「廃棄」を視野に入れるためにエントロピーを用いる。 このことにより、資源の投入・消費および、消費の結果 としての污染の発生・廃棄という一連の過程が定量的に 把握できることになり、既存の様々な建築環境システム が、どのようにして成り立っているか、更には建築環境 システムは本来どのようにして成り立たせるべきか等が 明確になると考えるからである(1)2,3)。

本報では、太陽エネルギー利用の一方法である昼光照 明を対象に、その計算理論にエントロピー・エクセル ギー概念を組み込むことを試み、昼光照明システムはい かにして成立しているのかを定量的に明らかにすること 
を目的とした4)。以下ではまず、昼光照明を行っている 室に扔けるエクセルギーの投入・消費、エントロピーの 生成・廃共の一連の流れを求的る計算方法について述 ベ、次にこの計算方法に基づいた簡単な数值計算を行 い、検討した結果について述べる。

2. 日射エネルギーのエントロピー・エクセルギー 太陽エネルギーはその利用目的によって「昼光」や 「日射熱」などと表現されることが多いけれども、太陽 エネルギーはそもそも可視域を主成分とする放射エネル ギーであるから、以下では放射エネルギーという意味で 「日射エネルギー」または「日射量」と表記する。

一般に、エクセルギー流 $e_{\mathrm{x}}\left[\mathrm{W} / \mathrm{m}^{2}\right]$ は、エネルギー流 $e_{\mathrm{n}}$ $\left[\mathrm{W} / \mathrm{m}^{2}\right]$ とそれに伴うエントロピー流 $s\left[\mathrm{~W} / \mathrm{m}^{2} \mathrm{~K}\right]$ から次の ように表わされる゙)。

$$
e_{x}=e_{n}-s \circ T_{o}
$$

ここで、 $T_{o}$ : 熟の捨て場の温度 $[\mathrm{K}]$ 。日射のエネルギー流 は、日射量として容易に与えられるから日射のエントロ ピー流を求めることができれば(1)式から日射エクセル ギー流が求められる。ここでは、日射のエントロピー流 の計算にKabelac らの式索用いることにした。法線面值 達日射のエントロピー流 $s_{D N}\left[\mathrm{~W} / \mathrm{m}^{2} \mathrm{~K}\right]$ は、

$$
s_{D N}=0.000462 \oplus\left(I_{D N}\right)^{0.9}
$$

ここで、 $I_{D N}$ : 法線面直達日射量 $\left[\mathrm{W} / \mathrm{m}^{2}\right]$ 。

同様に、水平面天空日射のエントロピー流 $s_{d i f}\left[\mathrm{~W} / \mathrm{m}^{2} \mathrm{~K}\right]$ は、

$$
s_{d j f}=0.0014 \oplus\left(I_{S H}\right)^{0.9}
$$

ここて、 $I_{s H}$ : 水平面天空日射量 $\left[\mathrm{W} / \mathrm{m}^{2}\right]$ 。(2),(3)式は Planckによって導かれた平衡系における黒体放射のエン トロピーの式を、非平衡系の放射である日射エネルギー に応用するため、日射の分光分布、天空の放射輝度分 布、大気による偏光の影響をいくつかの代表的な天気状 態について険討した結果から得られた簡易式である゙)。

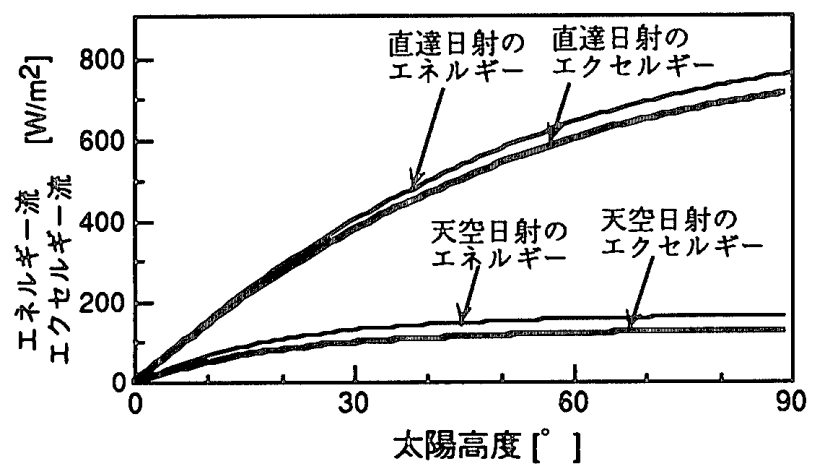

图 1 法線面直遧日射および水平面天空日射の エネルギーとエクセルギーの計算例

(熱の捨て場温度 $288 \mathrm{~K}$ )

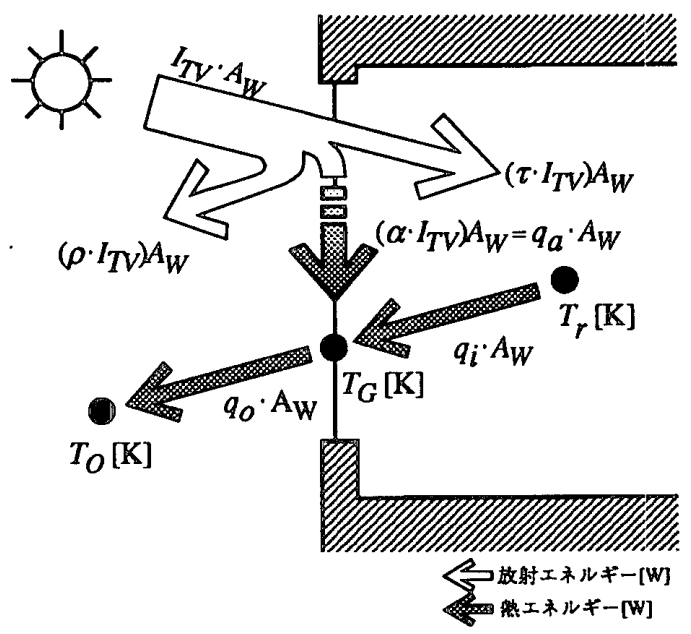

图 2 葖面に扔けるエネルギーの流れ

図1は快晴時を想定して、法線面直達日射および水平 面天空日射のエネルギー流とエクセルギー流の関係を求 めてみたものである。熱の捨て場の温度は、 $288 \mathrm{~K} て ゙ 一$ 定と仮定している。横軸は太陽高度、縦軸はエネルギー 流とエクセルギー流である。日射エネルギーに対する日 射エクセルギーの割合は、直達日射の場合約 $90 \%$ 、天空 日射の場合約 $80 \%$ ある。このことより、日射エネル ギーは非常に質の高いエネルギーであることが改的て確 認できる。

3. 昼光照明を行っている室におけるエクセルギー の投入・消賴とエントロピーの生成・廢寨

エネルギーの移動・形熊変化のあるところでエクセル ギーが消費され、エントロピーが生成される3)。そこ て、昼光照明を行っている室において日射エネルギーの 移動・形態变化のある各部位におけるエクセルギーの投 入・消費ならびにエントロピーの生成・廃棄をまず求 め、その結果を総合して室全体におけるエクセルギーの 投入・消費過程、エントロピーの生成・廃棄過程を求め ることにした。なお簡単のため室温、外気温等は一定で あると仮定し、空ガラスを透過する直達日射は一様拡散 するとした。

\section{3-4。㝕における光から熱への形態变化に伴う エントロピー生成}

図 2 は空面におけるエネルギーの流れを模式的に示し たものである。 $A_{W}$ は空面積 $\left[\mathrm{m}^{2}\right] 、 I_{T V}$ は空面に入射する全 日射量 $\left[\mathrm{W} / \mathrm{m}^{2}\right] 、 \tau 、 \alpha 、 \rho は$ はそれぞれ全日射に対する透 過率、吸収率、反射率である。 $q_{i} 、 q_{0}$ はそれぞれ空ガラ スの内表面熟流、外表面熱流 $\left[\mathrm{W} / \mathrm{m}^{2}\right]$ である。いずれも室 外側へ向かうものを正としている。 $T_{o}, T_{G}, T$ はそれぞれ 外気温、ガラス温度、室温 $[\mathrm{K}]$ である。

空面では1）日射エネルギーの吸収により光から熟へ 


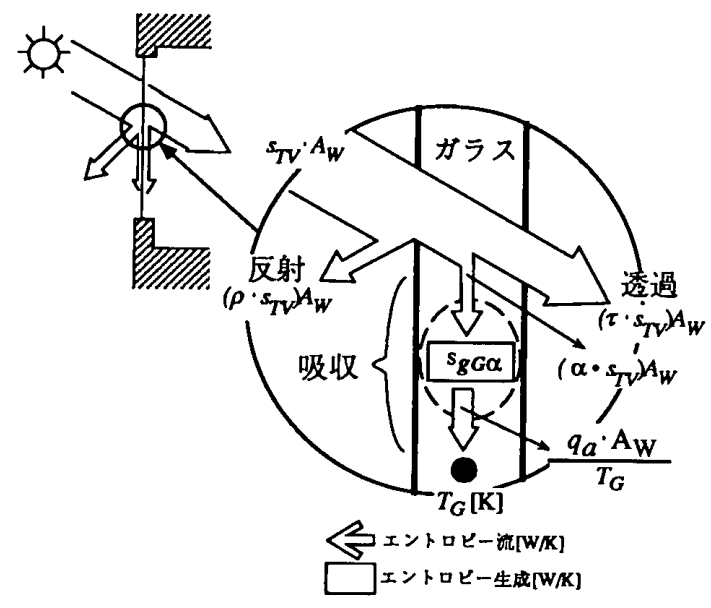

図 3 空ガラスの日射吸収の際のエントロビー流と エントロビー生成

の形態変化、2）室内空気から空ガラスを貫流して外気 への熱伝達による㲎エネルギーの移動がある。エネル ギー保存則より、空ガラス面におけるエネルギー収支 は、

$$
\alpha \bullet I_{T V}=q_{a}
$$

ただ、 $q_{a}\left[\mathrm{~W} / \mathrm{m}^{2}\right]$ は日射が空ガラスに吸収された結果の 熱である。図3を参照して、日射エネルギーが温度 $T_{G}[\mathrm{~K}]$ のガラスに吸収される際に生成されるエントロピーを

$s_{g G a}[\mathrm{~W} / \mathrm{K}]$ と表わすことにすると、空ガラス面における エントロピー収支は、

$$
\alpha \bullet s_{T V} \bullet A_{W}+s_{g G \alpha}=\frac{q_{a}}{T_{G}} \bullet A_{w}
$$

ここて、 $s_{T V}$ は鉛直面全日射量に伴うエントロピー流[W/ $\left.\mathrm{m}^{2} \mathrm{~K}\right] 。 s_{T V}$ は、付録 1 の(A.1.1)式から求められる。(5)式 の右辺は日射エネルギーがガラスに吸収された後の、即 ち日射熱 $q$ 。のエントロピー流である。(4)式、(5)式を整 理すると、

$$
s_{g G \alpha}=\frac{\alpha \bullet\left(I_{T V}-s_{T V} \bullet T_{G}\right) \bullet A_{W}}{T_{G}}
$$

(6)式右辺の分子の()内は、ガラス面を熱の捨て場と見な したときの日射エクセルギーである。

3-2. 空における熱伝達に伴うエントロピー生成 空の室内側表面における熟移動に伴うエントロピーの 移動と生成を模式的に図4に示す。この熱移動は総合热 伝達率 $h_{i}\left[\mathrm{~W} / \mathrm{m}^{2} \mathrm{~K}\right]$ を用いることにすれば、

$$
q_{i}=h_{i} \bullet\left(T_{r}-T_{G}\right)
$$

(7)式で表わされる熱伝達によるエントロピー生成を $s_{8 i}$ [W/K]とすれば、(7)式に対応するエントロピー収支式は 図4を参照して、

$$
\frac{q_{i}}{T_{r}} \cdot A_{W}+s_{g i}=\frac{q_{i}}{T_{G}} \bullet A_{W}
$$

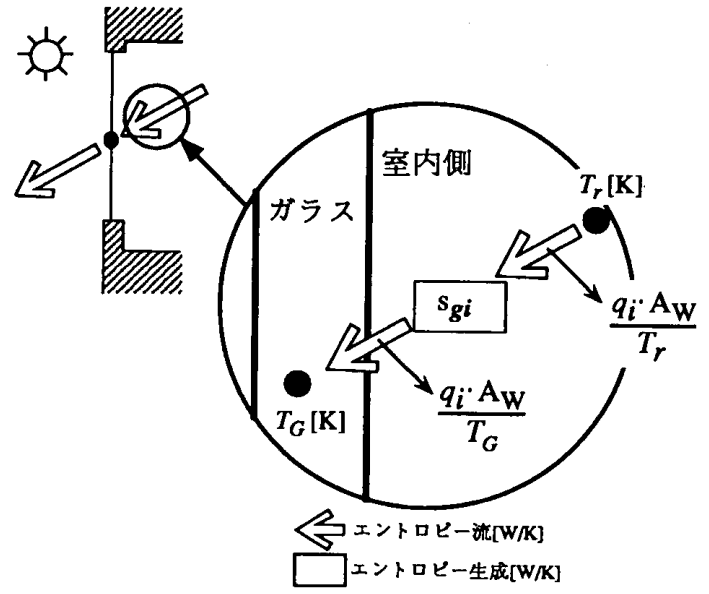

図 4 空ガラス室内側表面におけるエントロビー流と エントロビー生成

(7),(8)式を整理すると次式が得られる。

$$
s_{g i}=A_{W} \frac{h_{i} \bullet\left(T_{r}-T_{G}\right)^{2}}{T_{r} \bullet T_{G}}
$$

以上と同様に $T_{G}[\mathrm{~K}]$ の空ガラス外気側表面と $T_{o}[\mathrm{~K}]$ の外

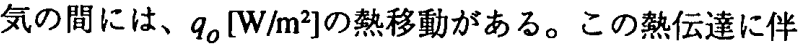
うエントロピー生成を $s_{80}[\mathrm{~W} / \mathrm{K}]$ とすると、 $s_{80}$ は次式で表 わすことができる。

$$
s_{g o}=A_{W} \bullet \frac{h_{o} \bullet\left(T_{G}-T_{o}\right)^{2}}{T_{G} \bullet T_{o}}
$$

ここで、 $h_{o}$ は外表面総合熱伝達率 $\left[\mathrm{W} / \mathrm{m}^{2} \mathrm{~K}\right]$ である。ただ し、(10)式を導くにあたり簡単のために実効放射はない と仮定している。

四5は空ガラス外気側におけるエントロピーの流れを 模式的に示したものである。空ガラスの内部には日射エ ネルギーの吸収で生成されたエントロピー（図3の $s_{g G \alpha} お$

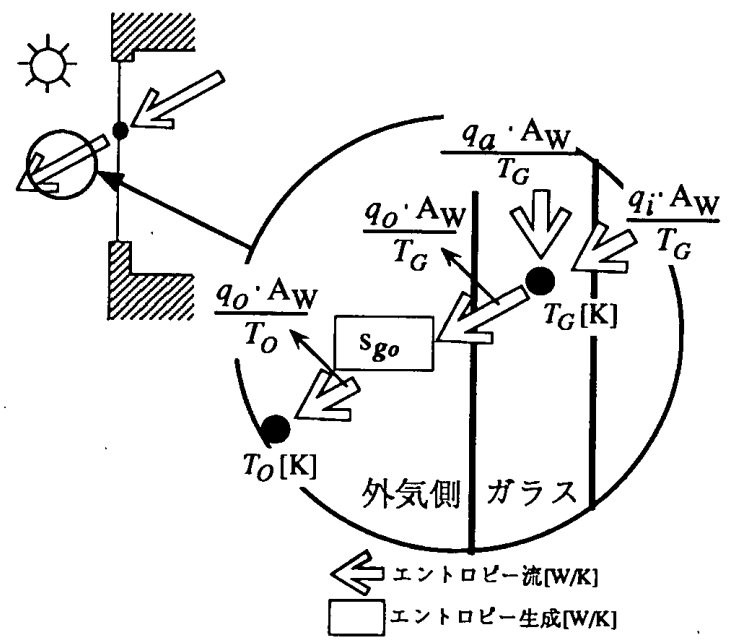

图 5 空ガラス外気側表面におけるエントロビー流と エントロビー生成 


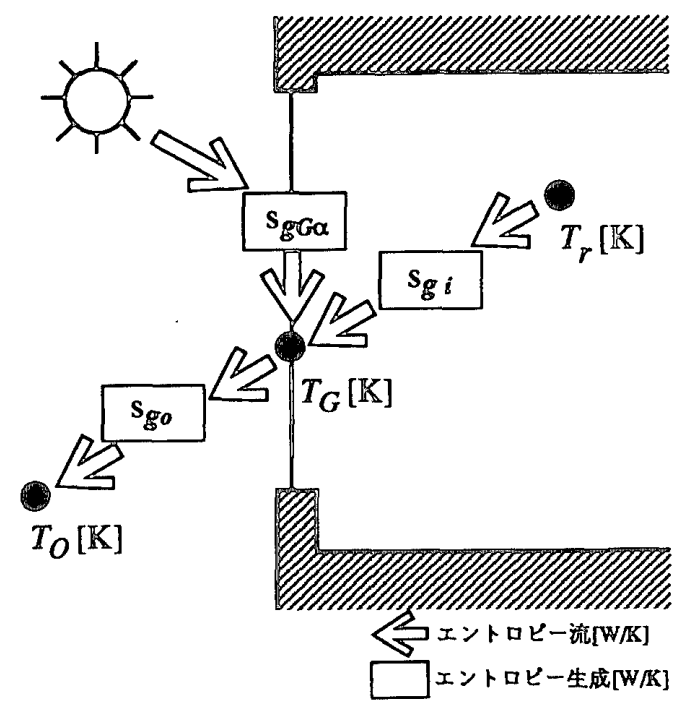

图 6 惌ガラス全体におけるエントロピー流と エントロビー生成

よび(6)式）と、窓ガラス室内側の勃移動で生成された工

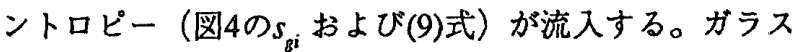
の温度 $T_{G}[\mathrm{~K}]$ は一定としているので、流入エントロピー はガラスに溜まらず熟伝達に伴って外気に廃衰されなけ ればならない。このエントロピー廃裹にも(10)式に示し た $s_{g o}$ のエントロピー生成が伴い、結局 $\frac{q_{0}}{T_{o}} \odot A_{W}[\mathrm{~W} / \mathrm{K}]$ のエ ントロピーが外気に廃裹される。図6は空面全体のエン トロピーの流れと生成の様子を示したものである。

\section{3.-3エクセルギーの消睍}

エントロピーの生成は、エクセルギーの消費に比例す ろ3)。最終的な热の捨て場を仮に外気とすれば、空面で の日射吸収による光から熱へのエネルギーの形態変化の 際のエクセルギー消費 $e_{c G a}[\mathrm{~W}]$ は(6)式の両辺に外気温 $T_{o}$ を乗じることによって求められる。

$$
\begin{aligned}
e_{c G a} & =T_{O} \oplus S_{g G \alpha} \\
& =A_{W} \oplus \alpha \cdot\left(\frac{T_{O}}{T_{G}}\right) \cdot\left(I_{T V}-s_{T V} \odot T_{G}\right)
\end{aligned}
$$

同様に室内側および外気側の熱伝達によるエクセルギー 消費をそれぞれ $e_{c i}, e_{c o}[\mathrm{~W} / \mathrm{K}]$ とすると、

$$
\begin{aligned}
& e_{c i}=T_{O} \oplus s_{g i}=A_{W} \cdot\left(\frac{T_{O}}{T_{G}}\right) \cdot \frac{h_{i} \cdot\left(T_{r}-T_{G}\right)^{2}}{T_{r}} \\
& e_{c o}=T_{O} \cdot s_{g o}=A_{W} \cdot \frac{h_{o}\left(T_{G}-T_{o}\right)^{2}}{T_{G}}
\end{aligned}
$$

3-4. 室内で生成されるエントロピーおよび

消費されるエクセルギー

以上と同様の理論式の展開を行うことにより、空面を 透過し室内に入射する日射 $\left(\tau \bullet I_{T}\right) \cdot A_{W}[\mathrm{~W}] に$ 含まれる日
射エクセルギーが、室内の各部位で消費されてエントロ ピーが生成され、廃裹される過程が導ける。ここでは、 その概要を説明する。

まず、ここでは空面を透過する直達日射はすべて一様 拡散するとしたので、直達日射が透過の際に拡散し、方 向性を失うことによりエントロピーが生成（エクセル ギーが消費）される。このときのエントロピー生成 $s_{B} G \tau$

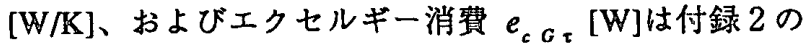
(A.2.1),(A.2.2)式より求められる。

次に、室内に入射した日射のうち照明という目的に寄 与する成分を $R_{S F}[\mathrm{~W}] と す る と 、 R_{S F}$ は図 7 に示すように 空面から直接受照面に入射する直接成分と、窒内表面で 相互反射したのち受照面に入射する間接成分の和とな る。一方、相互反射の過程で室内の壁体に吸収される日 射 $R_{m}[\mathrm{~W}]$ は、照明にまったく寄与することなく熱 $H_{m}[\mathrm{~W}]$ になる。 $R_{m}[\mathrm{~W}]$ は、

$$
R_{m}=H_{m}=\left(\tau \oplus I_{T V}\right) \oplus A_{W}-R_{S F}
$$

この日射吸収による光から熱への形態変化を「室内表面

第一次吸収」と表現すると、この現象によるエントロ ピー生成 $s_{g m}[\mathrm{~W} / \mathrm{K}]$ 抢よびエクセルギー消費 $e_{c m}[\mathrm{~W}]$ は付 録 2 の(A.2.3),(A.2.4)式から求められる。

照明として奇与した日射 $R_{S F}[W]$ 、最終的には室内の 壁体に吸収され熱 $H_{S F}[\mathrm{~W}]$ 形態変化する。これを「室内 表面 最終的吸収」と表現すると、この現象によるエン トロピー生成 $s_{B F}[\mathrm{~W} / \mathrm{K}]$ 抢よびエクセルギー消鄪 $e_{c F}[\mathrm{~W}]$ は付録 2 の(A.2.5), (A.2.6) 式より求的らる。壁体に吸 収された熱のエネルギー $H_{m}+H_{S F}\left(=\left(\tau \circ I_{T V}\right) \circ A_{W}\right)[\mathrm{W}]$ は、壁体に溜まることなく熟伝達によって室内空気に伝 わるとし、壁体の温度 $T_{m}$ [K]は一定で定常状態とする と、このときのエントロピー生成 $s_{g r}[\mathrm{~W} / \mathrm{K}]$ おびエクセ ルギー消費 $e_{c},[\mathrm{~W}]$ は付録 2 の(A.2.7), (A.2.8)式から求め られる。

冷房により室内から除去される熱を $H_{E}[$ W]とすると、 室内空気のエネルギー収支より、

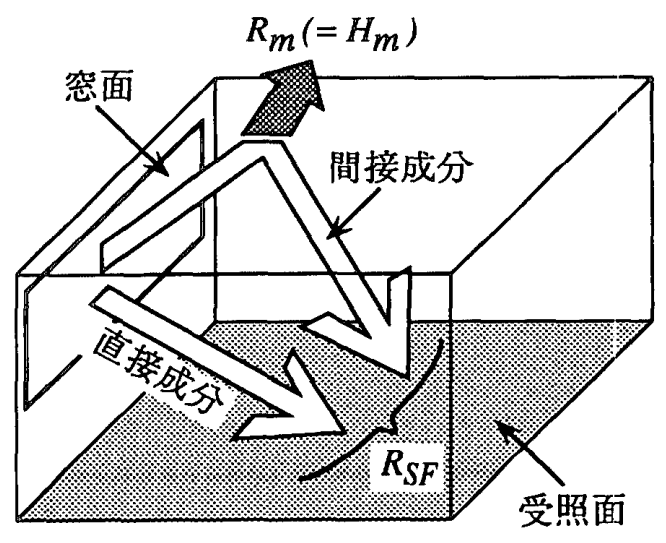

図 7 空透過日射の受照面に入射する成分と 壁体に吸収される成分 


$$
H_{m}+H_{S F}=h_{q} \bullet\left(T_{r}-T_{G}\right) \bullet A_{W}+H_{E}
$$

$H_{E}[\mathrm{~W}]$ の熱が温度 $T,[\mathrm{~K}]$ の室内から、温度 $T_{o}[\mathrm{~K}]$ の外気に

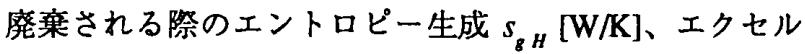
ギ一消費 $e_{c H}[\mathrm{~W}]$ は付録 2 の(A.2.9),(A.2.10)式から求めら れる。ただし、冷房設備の運転のためのエクセルギーの 投入と消費、エントロピーの生成と廃率の評価について はここでは論じないことにする。

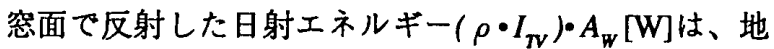
表面などに吸収され結局は熱になり、熱伝達によって外 気に伝わる。このときの日射吸収による光から熱への形 態変化の際にもエントロピー生成 $s_{8} G_{p}[\mathrm{~W} / \mathrm{K}]$ 扔よびエク セルギー消費 $e_{c G e}[$ W]がある。それらは付録 2 の(A.2.11), (A.2.12)式から求められる。

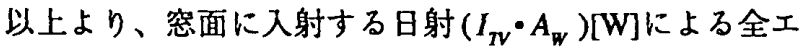
ントロピー生成 $s_{g \nu}[\mathrm{W} / \mathrm{K}]$ は、上記のエントロピー生成を すべて合計したものとなる。

$$
s_{g U}=s_{g G r}+s_{g G \alpha}+s_{g G p}+s_{g m}+s_{g F}+s_{g r}+s_{g H}
$$

(16)式に建物各部分におけるエネルギー収支式を代入し て整理すると、次式が得られる。

$$
s_{g U}=\frac{\left(I_{T V}-s_{T V} \bullet T_{o}\right) \bullet A_{W}}{T_{o}}
$$

(17)式の右辺の分子は、温度 $T_{o}[\mathrm{~K}]$ の外気を熱の捨て場と した場合の空面に入射する日射エクセルギーそのもので ある。つまり、(17)式は空面に入射する日射エクセル ギーは最終的にすべて消費され、エントロピーになって しまうことを示している。

\section{4 計算例と考察}

計算対象とした室は間口と愁行きが共に $5 \mathrm{~m}$ 、天井高が $2.6 \mathrm{~m}$ 、空面積が $8.5 \mathrm{~m}^{2}$ 、天井・壁・床の反射率がそれぞ

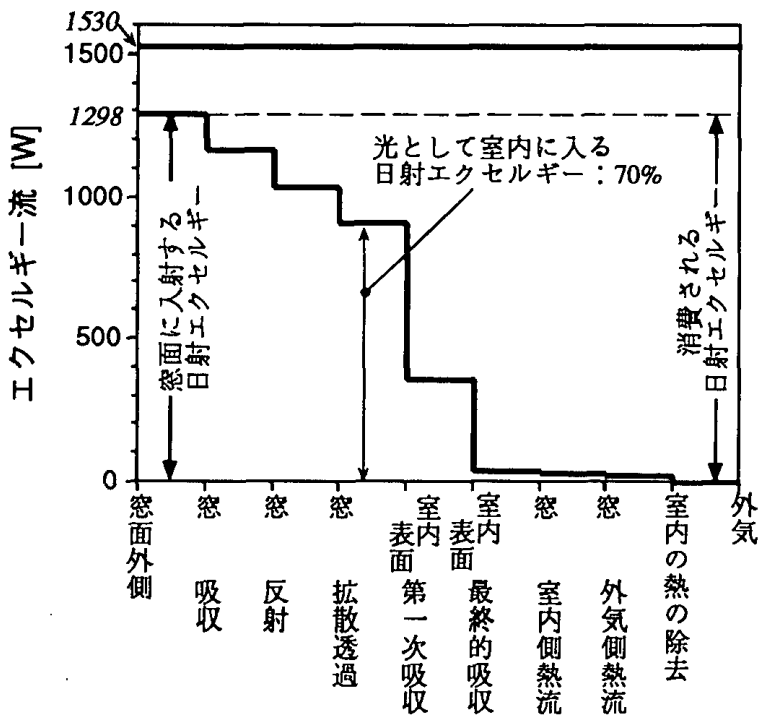

图 8 昼光照明を行っている室における エクセルギー消費
れ0.5、0.3、0.1の室である。外気温は $10^{\circ} \mathrm{C} 、$ 空以外の部 分は完全に断熟されており室温は $20^{\circ} \mathrm{C} に$ 保たれていると した。また、以下では簡単のため室内の壁体表面温 $T_{m}$ と 空気温 $T$,が等しくなるよう理想的に冷房が行われている とした。

\section{4-1. エクセルギーの投入とその消費}

図8は日射エクセルギーが消費されてゆく過程を具体 的に計算した結果の一例である。横軸はエクセルギーが 消費される部位と起きている現象を表わし、横軸右方向 が現象の起こる方向である。絴軸はエクセルギー流[W] である。横軸の各項目に対応して縦軸で階段状となって いる部分が、それぞれの現象によって消費されるエクセ ルギーである。

空面には1530Wの日射エネルギーが入射している。こ れは、鉛直面直達日射が $100 \mathrm{~W} / \mathrm{m}^{2}$ 、鉛直面天空日射が 80 $\mathrm{W} / \mathrm{m}^{2}$ を想定した場合で、水平面全日射量が $218 \mathrm{~W} / \mathrm{m}^{2}$ の 量天時に相当する。絴軸左端に矢印で示した部分は空面 に入射する日射エクセルギーで、この場合約 1300 Wであ る。ここでは、育ガラスの透過率を透明ガラスと同等な ものとしているので、ガラスを透過する成分が大きく、 吸収抢よび反射される成分は小さい。そのため、空面に 入射する日射エクセルギーの約70\%が光として室内に透 過する。室内平均照度は約 1600 lxである。また窓面に入 射した日射エネルギーは、3-4.に述べた「室内表面 最 終的吸収」という現象によって、すべて室温と同じ温度 の熱に形態変化する。その結果、はじめに持っていたエ クセルギーの約 $97 \%$ 消費される。つまり、室温と同じ 温度の熱となった 1530 Wの日射熟の持つエクセルギー は、空面に入射した日射エクセルギーの䄪 $3 \%$ である。 この3\%分のエクセルギーも、結局伝熱によってすべて消

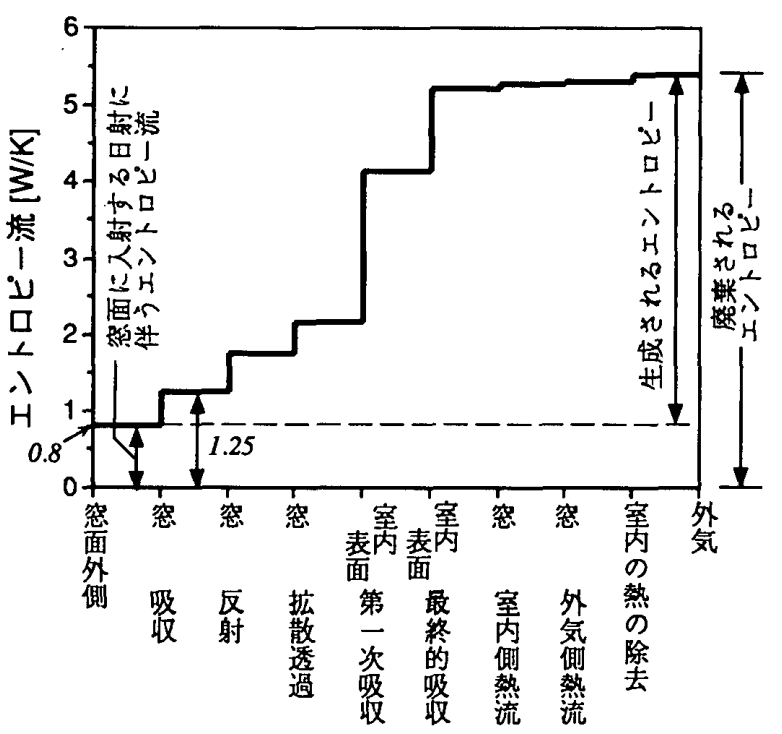

図 9 昼光照明を行っている室における エントロビー生成 


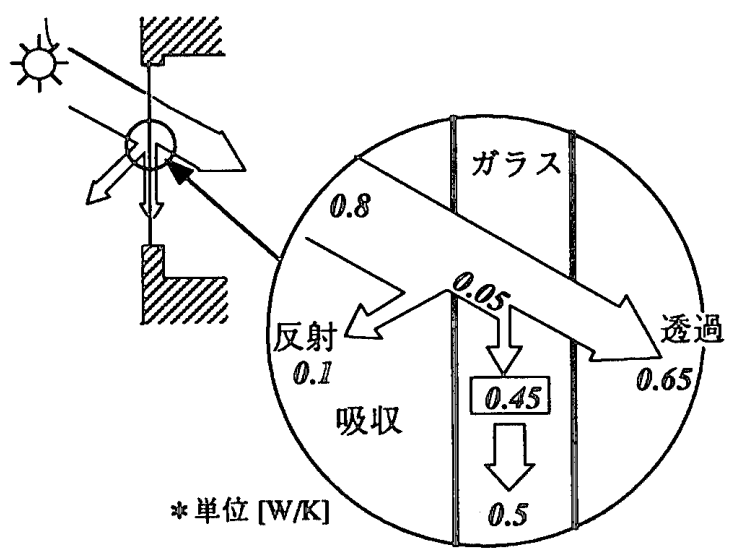

图10䓡ガラスの日射吸収に伴うエントロピー流と エントロピー生成

費される。図8の右端に矢印で示した部分は、最終的に 消費される全エクセルギーである。これは、空面に入射 する日射エクセルギーと等しい。

\section{4-2. エントロピー生成とその廃率}

図9は、図8のエクセルギー消費過程に対応するエント ロピー生成過程である。横軸はエントロピーが生成され る部位と起きている現象で、横軸右方向が現像の起こる 方向である。縦軸はエントロピー流 $[\mathrm{W} / \mathrm{K}]$ である。横軸 の各項目に対応して税軸て階段状となっている部分が、 それぞれの現象によって生成されるエントロピーであ る。図10は、図3に示した空面における日射吸収に伴う エントロピー生成の具体的な数値を示したものである。

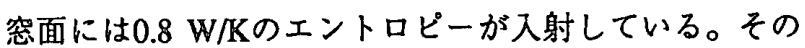
うち $0.1 \mathrm{~W} / \mathrm{K} は$ 空ガラスで反射され、0.65 W/Kは透過す る。残りの0.05 W/Kは空ガラスに吸収されるエントロ

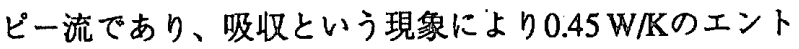
ロピーが生成され合計0.5 W/Kのエントロピー流がガラ ス内部に入ることになる。図9の「空 吸収」の項の右 側のエントロピー流は、図10に示したエントロピー流 $0.1,0.5,0.65 \mathrm{~W} / \mathrm{K}$ 和 $1.25 \mathrm{~W} / \mathrm{K}$ あ゙る。ここではガラス の温度を一定としているので、生成されるエントロピー はガラス内に溜まらずにすべて外気に捨てられなければ ならない。以上のようなエントロピーの廃裹は空ガラス だけでなく室の各部位で行われ、結局図9の右側に矢印 で示した部分のエントロピーが外気に廃棄される。室温 を $20^{\circ} \mathrm{C}$ に保ちつつ、昼光照明を行うためには図8に示し た日射エクセルギーの投入・消費と同時に、図9の右側 に矢印で示したエントロピーの廃裹が常に行われなけれ ばならない。

\section{4-3. 透明ガラスと熱線反射ガラスの比較}

図11は透明ガラスおよび熱線反射ガラスのある室にお けるエクセルギー消費過程を示したものである。なお、 ここでは晴天時を想定し、空面には直達日射が500 W/

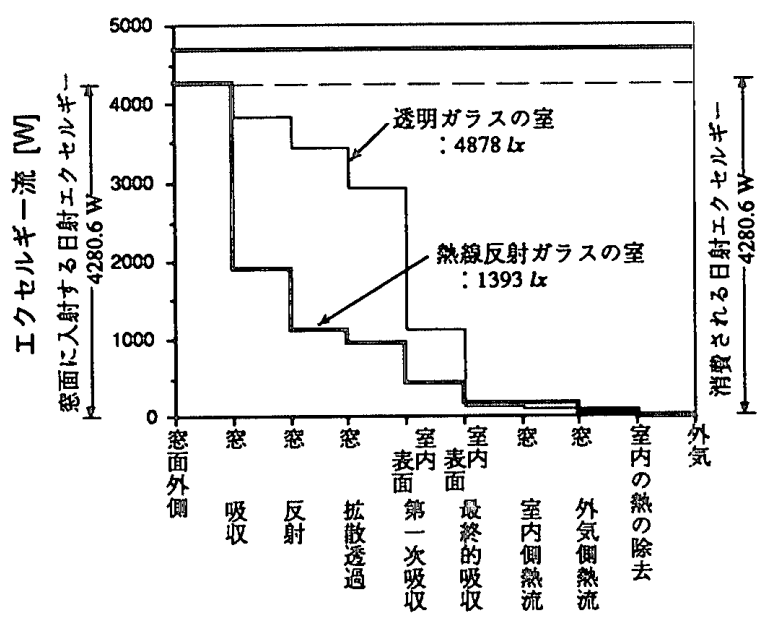

图11透明ガラスと熱線反射ガラスの エクセルギー消費過程

$\mathrm{m}^{2}$ 、天空日射が $50 \mathrm{~W} / \mathrm{m}^{2}$ 、空面全体で $4675 \mathrm{~W}$ の日射エネ ルギーが入射しているとした。また、透明ガラスおよび 熟線反射ガラスのいずれの場合も、簡単のため透過した 直達日射は一様拡散すると仮定した。透明ガラスの場 合、ガラスの透過率が高いため空面で消費されるエクセ ルギーが小さく、室内に透過するエクセルギーが大きく なり、室内の平均照度は $4878 l x$ と高くなっている。室内 の光環境は良好ではないと考えられる。

一方、熟線反射ガラスの場合、ガラスの透過率が低く吸 収率が高いので空面で消費されるエクセルギーが大きく なっている。そのため、室内には照明に必要な約 $1000 \mathrm{~W}$ の日射エクセルギーだけが入射することになり、室内平 均照度は約 $1400 l x$ とほほ適切な照度が得られることにな る。この約 $1000 \mathrm{~W}$ というエクセルギーの值は、図8に示 した畺天時の場合とほほ同じである。つまり日射が多い 日の場合、熱線反射ガラスは余分な日射エクセルギーを 空面で積極的に消費させるので、室内の光環境を損ねる ことなく昼光照明を行うことができることを意味する。 透明ガラスのある室と熱線反射ガラスのある室の双方に 投入される日射エクセルギーと、最終的に消費されるエ クセルギーは等しい。このことから、適切な昼光照明と は、日射エクセルギーが最終的にすべて消費されるまで の消費の過程を照明という目的に合うような過程に積極 的に变えることだと言える。

\section{5. 結論}

昼光照明システムの計算理論にエントロピーとエクセ ルギーの概念を組み込むことを試み、簡単な数値計算例 を挙げて考察を行った。その結果をまとめると、

1）日射エネルギーの中に含まれるエクセルギー（日射 エクセルギー）は、直達日射の場合その約 $90 \%$ 、天空

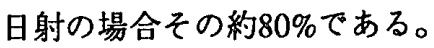


2）エントロピー・エクセルギーを用いることにより、 日射エネルギーの光から熱への不可逆的なエネル ギー変換過程を定量的に示すことができた。

3）疍光照明は日射エクセルギーが室内に投入され、そ のすべてが消費され、消費の結果生成されるエント ロピーが周囲の環境に廃寨されることによって成立 していることを具体的に示すことができた。

4）透明ガラスの場合、空面に入射する日射エクセル ギーの約70\%は、室内の照明用光源としてのポテン シャルを持っている。しかしながら、このエクセル ギーも日射エネルギーが室内で常温付近の熱に形態 変化する過程で、そのほとんどが消費される。

5）適切な昼光照明とは、日射エクセルギーが最終的に すべて消費されるまでの消費の過程を照明という目 的に合うような過程に積極的に変えることである。

\section{付録1}

鉛直窓面に入射する全日射エネルギーに伴うエントロビー流 $s_{T V}\left[\mathrm{~W} / \mathrm{m}^{2} \mathrm{~K}\right]$ は、

$s_{T V}=s_{D N} \bullet \cos \theta_{i}+0.5 s_{d i f}+0.5 s_{R H}$

$s_{D N}$ は(2)式、 $s_{\text {d仙 }}$ は(3)式より求められる。また、 $s_{R H}$ は地表面反 射日射のエントロビー流であり、(3)式で $I_{s H}$ の代わりに地表面 反射日射量を代入して求めることにした。 $\theta_{i}$ は直達日射の秌面 に対する入射角[rad]。

\section{付録 2}

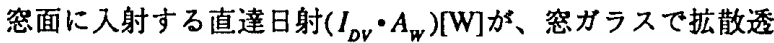
過する際に生成されるエントロピー $s_{8 G \tau}[\mathrm{W} / \mathrm{K}]$ は、应散した後 の日射のエントロビー流の計算に(3)式を用いることにすると、

$$
s_{g \propto t}=\left\{0.0014 \bullet\left(\tau_{D\left(\theta_{1}\right)} \bullet I_{D v}\right)^{o g}-\tau_{\left.D \theta_{1}\right)} \bullet s_{D N}\right\} \bullet A_{w}
$$

ここで、

$\tau_{\mathrm{D}}\left(\theta_{i}\right)$ : 窓ガラスの直達日射に対する透過率[ - ] $I_{D V}:$ 空面に入射する直達日射 $\left[\mathrm{W} / \mathrm{m}^{2}\right]$

また、消費されるエクセルギー $e_{\mathrm{c} G q}[\mathrm{~W}]$ は、

$e_{c G t}=T_{O} \bullet S_{o G t}$

照明に全く寄与されることなく壁に吸収される日射 $R_{m}[\mathrm{~W}]$ が、 熱 $H_{m}[\mathrm{~W}] に$ 形態変化する際のエントロビー生成 $s_{8 m}[\mathrm{~W} / \mathrm{K}]$ およ び、エクセルギー消費 $e_{\mathrm{cm}}[\mathrm{W}]$ は、

$$
\begin{aligned}
& s_{g m}=\frac{H_{m}}{T_{m}}-\frac{R_{m}}{\left(\tau \bullet I_{T V}\right) \bullet A_{W}} \bullet\left(\left(\tau \bullet s_{T V}\right) \bullet A_{W}+s_{g G \tau}\right) \\
& e_{c m}=T_{o} \bullet s_{g m}
\end{aligned}
$$

\section{ここで、 $T_{\mathrm{m}}:$ 壁体の平均表面温 $[\mathrm{K}]$ 。}

一方、室内で照明に寄与した成分 $R_{s F}$ が壁体に吸収され熱 $H_{s F}$

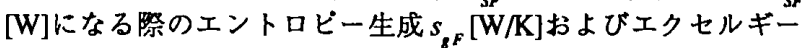
消費 $e_{\mathrm{c} F}[\mathrm{~W}]$ は、

$$
\begin{aligned}
& s_{g F}=\frac{H_{S F}}{T_{m}}-\frac{R_{S F}}{\left(\tau \bullet I_{T V}\right) \bullet A_{W}} \cdot\left(\left(\tau \bullet s_{T V}\right) \bullet A_{W}+s_{g \dot{G}}\right) \\
& e_{c F}=T_{o} \bullet s_{g F}
\end{aligned}
$$

壁体に吸収される日射エネルギー $\left(\tau \cdot I_{T V}\right) \cdot A_{W}\left(=R_{m}+R_{S F}\right)$ が 熟 $H_{m}+H_{s F}$ となり、室内空気に伝わる䅎のエントロビー生成 $s_{g r}[\mathrm{~W} / \mathrm{K}]$ おうびエクセルギー消費 $e_{\mathrm{c} r}[\mathrm{~W}]$ は、

$$
\begin{aligned}
s_{g r} & =\frac{h_{i} \bullet\left(T_{m}-T_{r}\right) \bullet A_{T}}{T_{r}}-\frac{h_{i} \bullet\left(T_{m}-T_{r}\right) \bullet A_{T}}{T_{m}} \\
& =\frac{h_{i} \bullet\left(T_{m}-T_{r}\right)^{2}}{T_{m} \bullet T_{r}} \\
e_{c r} & =T_{o} \bullet s_{g r}
\end{aligned}
$$

ここで、 $A_{T}:$ 室内の全表面積 $\left[\mathrm{m}^{2}\right]$ 。

冷房による除去熱量 $H_{E}[\mathrm{~W}]$ が温度 $T,[\mathrm{~K}]$ の室内から温度 $T_{0}[\mathrm{~K}]$ の

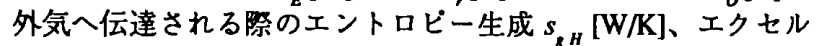
ギー消費 $e_{\mathrm{cH}}[\mathrm{W}]$ は、

$$
\begin{aligned}
s_{g H} & =\frac{H_{E}}{T_{O}}-\frac{H_{E}}{T_{r}} \\
e_{c H} & =T_{O} \bullet s_{g H}
\end{aligned}
$$

冷房装置の運転によるエクセルギー消費がなければ、上記の $H_{E}$ を室内から外気へ運ふことはできないけれども、それについて はここでは論しないことにする。

空面で反射する日射エネルギー $\left(\rho \cdot I_{T V}\right) \cdot A_{W}[W]$ は、地表面など に吸収され熱になり熱伝達によって外気に伝わる。このときの 日射吸収により光から、温度 $T_{o}[\mathrm{~K}]$ の熱への形態変化の䟢のエ ントロビー生成 $s_{s G_{p}}[\mathrm{~W} / \mathrm{K}]$ およ゙エクセルギー消費 $e_{c c_{p}}[\mathrm{~W}]$ は、

$$
\begin{aligned}
& s_{g G \rho}=\frac{\left(\rho \bullet I_{T V}\right) \cdot A_{W}}{T_{o}}-\left(\rho \bullet s_{T V}\right) \bullet A_{W} \\
& e_{c G \rho}=T_{o} \bullet s_{g G \rho}
\end{aligned}
$$

\section{記号表}

$A_{\tau}:$ 室内の全表面積 $\left[\mathrm{m}^{2}\right]$

$A_{\mathrm{w}}:$ 空面積 $\left[\mathrm{m}^{2}\right]$

$e_{x}:$ エクセルギー流[W/ $\left./ \mathrm{m}^{2}\right]$

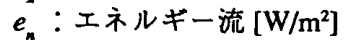

$e_{c G \alpha}$ : ガラスの日射吸収に伴うエクセルギー消費[W]

$e_{c i}, e_{c o}$ : 空ガラスの室内㑡および外気㑡の熱伝達によるエ クセルギー消費 [W/K]

$e_{c G 1}$ ：空ガラスで日射が拡散透過する際のエクセルギー 消費 $[\mathrm{W}]$

$e_{c G_{\rho}}$ : 空ガラスで反射する日射が熱になる際のエクセル ギー消費 [W]

$e_{c F}$ : 日射が室内表面で最終的に吸収される際のエクセ ルギー消費[W]

$e_{c H}:$ 室内の熱除去の際のエクセルギー消費[W]

$e_{c m}$ : 日射が室内表面で第一次吸収される際のエクセル ギー消費 $[\mathrm{W}]$

$e_{c,}$ : 壁体内の熟が室内空気に流れる際のエクセルギー 消費 $[\mathrm{W}]$

$H_{\varepsilon}$ ：冷暖房により室内から除去される熱[W]

$h_{i}, h_{0}$ : 空ガラス室内側および外気側の総合熱伝達率 $\left[\mathrm{W} / \mathrm{m}^{2} \mathrm{~K}\right]$

$I_{D N}:$ 法線面直達日射量 $\left[\mathrm{W} / \mathrm{m}^{2}\right]$

$I_{D V}$ : 鉛直空面に入射する直達日射量 $\left[\mathrm{W} / \mathrm{m}^{2}\right]$

$I_{S H}:$ 水平面天空日射量 $\left[\mathrm{W} / \mathrm{m}^{2}\right]$

$I_{T v}$ : 鉛直面に入射する全日射量 $\left[\mathrm{W} / \mathrm{m}^{2}\right]$

$q$ ：空ガラスに吸収された日射熱 $\left[\mathrm{W} / \mathrm{m}^{2}\right]$

$q_{i}, q_{o}:$ 空ガラスの室内側および外気側の熱伝達によって 移動するエネルギー $\left[\mathrm{W} / \mathrm{m}^{2}\right]$

$H_{m}$ : 室内に入射した日射エネルギーの一部が、照明に 奇与せずに壁体に吸収された結果の熱[W] 
$H_{S F}$ : 照明に寄与した日射エネルギーが壁体に吸収され た秸果の熟[W]

$R_{r}$ ：照明に寄与することなく壁内表面に吸収される日 射エネルギー $\left[\mathrm{W} / \mathrm{m}^{2}\right]$

$R_{S F}$ : 照明に奇与する日射エネルギー $\left[\mathrm{W} / \mathrm{m}^{2}\right]$

$s:$ エントロピー流 [W/ $\left./ \mathrm{m}^{2} \mathrm{~K}\right]$

$s_{D N}$ : 法線面直達日射エントロピー流 $\left[\mathrm{W} / \mathrm{m}^{2} \mathrm{~K}\right]$

$s_{d i f}$ : 水平面天空日射エントロピー流 $\left[\mathrm{W} / \mathrm{m}^{2} \mathrm{~K}\right]$

$s_{R H}$ : 水平面に入射する地表面反射日射エントロピー流 [W/m $\left./ \mathrm{m}^{2} \mathrm{~K}\right]$

$s_{T}$ : 鉛直面全日射量に伴うエントロピー流 $\left[\mathrm{W} / \mathrm{m}^{2} \mathrm{~K}\right]$

$s_{{ }_{B} G_{a}}$ : ガラス内の日射吸収に伴うエントロピー生成 [W/K]

$s_{b G F}$ ：日射が空内表面で最終的に吸收される際のエント ロピー生成 [W/K]

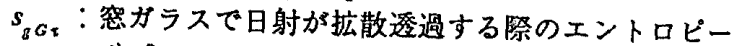
生成 [W/K]

$S_{q} G_{p}$ : 空ガラスで反射する日射が熟になる際のエントロ ピー生成 [W/K]

$s_{g i}, s_{80}$ : 慧ガラスの室内側および外気側の熱伝達によるエ ントロビー生成[W/K]

$s_{s H}$ : 室内の熟除去の際のエントロピー生成[W/K]

$s_{B m}$ :日射が室内表面で第一次吸収される際のエントロ ピー生成[W/K]

$s_{z}$ ：壁体内の熱が窒内空気に流れる際のエントロピー 生成[W/K]

$s_{g} u$ : 空面に入射する日射による全エントロビー生成 [W/K]

$T_{o}, T_{G}, T$ ：外気、窑ガラス、室内空気の温度[K]

$T_{r z}$ : 壁体の平均表面温度 $[\mathrm{K}]$

$\theta_{i}$ : 直達日射の空面に対する入射角[rad]

$\tau_{D}\left(\theta_{i}\right)$ : 空ガラスの直達日射に対する遥過率[ - ]

$\tau, \alpha, \rho$ : 恝ガラスの全日射に对する透過率、吸収率、反射 率[ - ]
骖势立献

1）宿谷昌則；建築瓄境システムとエントロピー・エクセル ギー（その1.建築環境システムの持続可能性）、日本建築 学会大会学術满演梗概集、pp.49-50、1993年。

2）宿谷昌則；エントロビー・エクセルギー概念の建築理境論 への応用とその課題、空気調和衛生工学会学術檴倾論文 集、pp.265-268、1993年。

3）宿谷昌則；光と熱の建筑垶境学、丸善、pp.235-269、1993 年。

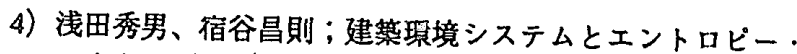
エクセルギー（その2.照明システム成立のメカニズム）、 日本建築学会大会学衍講演梗概集、pp.51-52、1993年。

5) Kabelac,S. and Drake,F.-D. ; THE ENTROPY OF TERRESTRIAL SOLAR RADIATION, Solar Energy, Vol.48, No.4, pp.239-248, 1992.

(1993 年 9 月 30 日原稿受理, 1994 年 4 月 20 日採压決定) 